\title{
THE ANTECEDENTS AND CONSEQUENCES OF SERVICE RECOVERY PERFORMANCE OF FRONTLINE EMPLOYEES: A STUDY OF VIETNAM RETAILING INDUSTRY
}

\author{
Tran Van Hung \\ University of Finance and Marketing, Ho Chi Minh City, Vietnam \\ Vo Thi Ngoc Lien \\ University of Finance and Marketing, Ho Chi Minh City, Vietnam
}

\begin{abstract}
Previous studies on service recovery performance have merely focused on identifying the factors which affect it from the service provider side. This study investigates the effect of customer participation on Vietnam retailing service recovery performance. A structural model was developed and tested using data surveyed from 231 respondents who were currently full-time employees in Vietnam retailers. The results show that the more customer participation which frontline employees perceive, the more effective the service recovery they perform. Moreover, the results indicate that the more effective service recovery which frontline employees perform, the less stress they confront. Empowerment of and training for employees have an equivalent impact on the service recovery performance of frontline employees. However, there is no significant relationship between service recovery performance and intention to leave of frontline employees.
\end{abstract}

Keywords: service recovery performance; customer participation; Service-Dominant Logic, Vietnam retailing

DOI: http://dx.doi.org/10.15549/jeecar.v8i3.667

\section{INTRODUCTION}

Retailing plays a significant role in an economy which contributes to Gross Domestic Product, and it also is a major source of jobs for every country. According to Bent and Freathy (1997), retailing is seen as a labor-intensive industry. For that reason, frontline employees, because they are the first people with whom customers have contact, still play a critical role in retailing. Therefore, frontline employees' behaviors and their task performance will create an impression about retailers and partially affect customer experience and satisfaction (Gwinner et al., 2005; Hennig-Thurau et al., 2006;).

Although playing a critical role, frontline employees in retailing usually have to bear stress at work such as work in shifts and extra hours in 
peak seasons, yet it is the lowest-paid position in a retailer. Based on a survey done by Navigos Group (NG, 2017), a headhunter in Vietnam, 49\% of retailers reveal they have to face high staff turnover, and retailing is one of the top three industries which has the highest staff turnover in Vietnam; $60 \%$ of employees in the survey say they have worked in a company for an average of 2-3 years.

While it is easier to make mistakes in laborintensive industries like retailing, it is inevitable to avoid failures that might reduce customers' positive emotions of joy and happiness (Wen and Chi, 2013). However, service failures may lead to positive outcomes such as customer satisfaction, positive word of mouth, and repurchase intentions if they are resolved effectively (Xu, Liu, and Gursoy, 2019). Nevertheless, under the poor working conditions frontline employees face and their low pay, there is an emerging concern the quality of their service recovery behavior. Will employees feel more stressed having to deal with complaining customers and intend to leave, or will they take it as a chance to learn from their mistakes and improve their performance?

Based on Service-Dominant Logic, value is always co-created through resource integration between many actors in a network and the customer is the only entity to create value and benefits for all actors (Vargo et al., 2004). Thus, firms can only design the recovery process and train employees to deal with complaining customers but cannot re-create value through the recovery process without customer participation. Existing knowledge has been focusing on the benefits of customer participation, however there are only a few studies that discuss the dark sides of customer participation such as failed co-developed services (Blut, Heirati, Schoefer, 2019). Therefore, a question arises about how customers affect frontline employee service recovery performance and bring benefit for employees during the co-creation process. It is surprising that there is no related empirical research in the Vietnam context. Therefore, this study aims to fill this gap through a narrative review of the scientific literature and identify the factors to affect frontline employees' service recovery performance.

\section{LITERATURE REVIEW}

Service-Dominant Logic and Service Recovery Performance of Frontline Employees:

It is obvious that service failures make customers dissatisfied, and retailers will face the negative consequences by losing their potential customers through negative word of mouth. However, there is another chance for retailers to win their customers back through the service recovery performance of frontline employees. As frontline staff is normally the first port of call for a dissatisfied customer, the most effective service recoveries are those solved immediately by frontline staff (Zeithaml, Bitner, and Dremler, 1996). According to Gronroos (1988), service recovery is the action of a provider in response to failures.

Indeed, many researchers have found that if customers experience great recovery, they would be happier and would spread positive worth of mouth to their life circle members (Andreassen and Lindestad, 1998). Vargo and Lusch (2004) argued that in Service-Dominant Logic, value is co-created through resource integration among many actors. Service recovery is seen as an individual focus approach (Krishna, Dangayach, and Jain, 2011), whereas the cocreation concept allows customers to personalize the content of their experience. When service recovery is not a post-purchase stage, co-creation in service recovery can help to shape the content of recovery with the service provider through collaboration (Roggeveen, Tsiros, and Grewal, 2012). Although service recovery is an old concept, the role of customers has not been examined carefully when service failures occur (Dong, Evans, and Zou, 2008). Recent research has shown the benefits from the customer side after a co-created service recovery such as customer satisfaction and repurchase intentions (e.g., (Cheung and To, 2016). There is still a concern, however, about whether service firms get benefits from customer participation. More empirical studies on co-creation in service recovery are necessary (Hazée, Van Vaerenbergh, and Armirotto, 2017)

\section{Theoretical Model:}

Based on the view of Service-Dominant Logic, customers are not merely receivers (Xie, Bagozzi, 
and Troye, 2008). Instead, customers with their operant resources (knowledge and skills) integrate with resources from providers (tools, employee knowledge, and skills) to create and optimize their value in use. Therefore, firms can design a recovery process and train their employees to deal with complaining customers, but they cannot re-create value through the recovery process. Roggeveen, Tsiros, and Grewal (2012) identified that co-created service recovery is the ability to shape or personalize the content of recovery through joint-collaboration with the service provider. According to Hazée, Vaerenbergh, and Armirotto (2017), when problems occur, customers must provide and discuss the current problems with the frontline staff. More than that, the discussion with frontline staff allows customers to exert more personal control and increase the probability of attaining the optimal outcome (Thibaut and Walker (1975), and control over the process and recovery solutions (Guo et al., 2016). Customer participation in the recovery process additionally creates an outcome for frontline staff by sharing information about the errors, being friendly, patient, or even keeping calm throughout the interaction. Therefore, frontline staff can perform their recovery behaviors effectively. The following hypotheses are thus considered:

H1: Perceived customer participation is positively related to the service recovery performance of frontline employees.

H2: Training for frontline employees is positively related to the service recovery performance of frontline employees.

Parasuraman (1987) indicated that the culture which exists within a service firm has a strong influence on the firm's ability to provide excellent service and to effectively recover from service breakdowns. A company with a customer orientation philosophy will outperform competitors in anticipating customers' needs and improving service (Brady and Cronin, 2001). In a firm that views complaining to customers as a nuisance, employees are unlikely to be pleasant and empathetic in dealing with non-routine services such as complaints (Parasuraman, 1987). Because Vietnam is a collectivistic culture in which the value of the family and community comes before oneself, it is hypothesized that:

H3: Customer service orientation of the firm is positively related to the service recovery performance of frontline employees.

According to Bowen and Lawler (1992), empowerment is giving employees the power to act in the interest of serving customers better and, thus, to influence organizational performance. Paynevandy (2016) also indicated empowerment does not simply mean giving power to employees in making decisions; it also is important to let them learn by their experience and motivate employees to improve or renovate their performance. While empowerment gives the authority for employees to perform to their best capability, training gives the knowledge and skills employees need to perform in the right way. Unfortunately, some researchers have indicated that customer contact staffs are often not given the authority they need to provide the required level of service (Rust, Zahorik, and Keiningham, 1996), particularly in the event of a service failure (Bowen and Lawler, 1992). This study therefore suggests the following hypothesis:

H4: Empowerment of frontline employees is positively related to their service recovery performance

Job stress refers to workers' feelings of jobrelated tension, anxiety, frustration, worry, emotional exhaustion, and distress (Cullen et al., 1985). It is obvious that job stress will affect employees' physical and mental health and their performance at work (e.g., Beehr, Walsh, and Taber, 1976). When failures occur, customers who come back to complain to retailers usually are in a negative mood because of the inconvenience they have to bear. Therefore, dealing with complaining customers adds more pressure for frontline employees to calm customers down. Moreover, the recovery process requires providing more information, and sometimes retailers need to compensate for customers' loss plus add extra value for their inconvenience. In general, the frontline employee is in between, facing pressure from both the customer side and his or her manager during the recovery process. Thus, the following hypothesis:

H5: Service recovery performance of frontline employees is negatively related to job stress

According to Boshoff and Allen (2000), turnover is particularly serious for service firms 
that often rely on long-term customer-supplier relationships to retain customers. Intention to leave refers to an inner process to examine the probability to leave or stay in the organization in the near future (Zaman, Iftikhar, \& Rana, 2019). When employees intend to leave, they may not put in the effort to work harder or improve themselves to work effectively. If frontline employees cannot perform recovery effectively, customers maybe not be satisfied, which could lead to losing customers or negative outcomes in their work and could heighten their intention to leave the job. Ashill et al (2005) also indicated that effective service recovery performance leads employees to a greater level of satisfaction. Previous studies also have supported the idea that service recovery performance is a predictor of intention to leave (see e.g., Zaman, Iftikhar, \& Rana, 2019). It is therefore hypothesized that::

H6: Service recovery performance is negatively related to the intention to leave by frontline employees.

H7: Job stress is positively related to the intention to leave by frontline employees

Figure 1 represents a hypothesized model for this study

Figure 1: Proposed hypothesized model

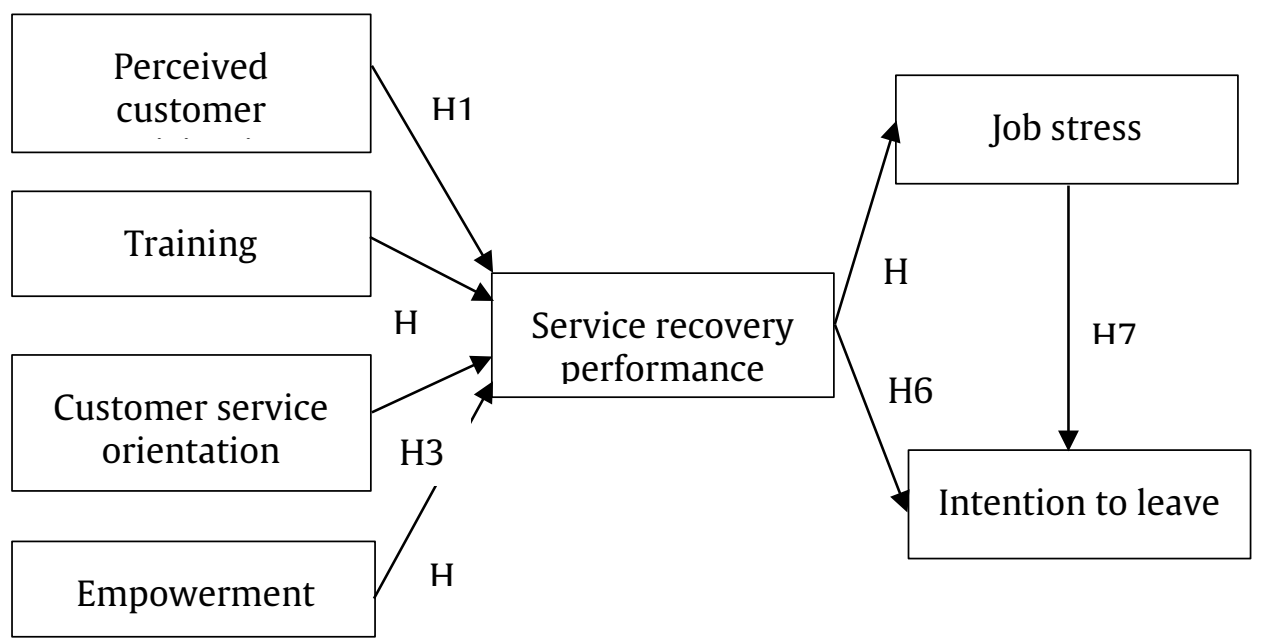

Source: authors' work.

\section{METHOD}

The questionnaire was initially developed in English, then was translated into Vietnamese via back-translation with the support of 2 professors who are fluent in both languages (Pym 2010). The measures used in this study were obtained from the literature review. A focus group was organized to interview 5 managers who were working for retailers to adjust item wording of the preliminary questionnaire to fit the retailing context. A revised version was used in pretesting 30 full-time retail employees. The target respondents were full-time frontline employees at retailers in Ho Chi Minh City, Vietnam. The data collectors connected with the Human Resource Department in the retail firms for their permissions to deliver printed questionnaires to frontline employees at lunchtime. The questionnaire was designed to be answered anonymously, therefore respondents were free to give their opinions. The use of convenience sampling was the only option available, as it was not possible to obtain a sampling frame in order to draw a simple random sample. The sample size is 231. All the scales were designed in fivepoint Likert type. Empowerment for employee measurement is adapted from Hayes (1994) with 5 items. Training for employee measurement is adapted from Boshoff and Allen (2000) with 7 items. Customer orientation of the firm measurement is adapted from Zeithaml et al. (1996), and Futrell et al. (1984) with 9 items. The perceived customer participation behaviour measurement was adapted from Yi and Gong (2013) with 2 second-order factors - information 
sharing (4 items) and personal interaction (5 items). Service recovery performance of frontline employee measurement is adapted from Boshoff and Allen (2000) with 5 items. Job stress measurement is adapted from Griffin, Hogan, Lambert, Tucker-Gail, and Baker (2010) with 5 items. Intention to leave measurement is adapted from Boshoff and Allen (2000) with 3 items.

\section{RESULTS}

All 43 items were added to run Exploratory Factor Analysis (EFA) to cut off unqualified items. Methods of Extraction Principal Axis Factoring Analysis with the Promax rotation method were used in this step. Confirmation Factor Analysis was used to test the measurement model. Items with factor loading less than 0.5 and high modification index (MI) were cut off. Model fit: P-value $=0.000$; Chi-square $=228.500, \mathrm{df}=142$; Chi-square $/ \mathrm{df}=1.609<2.0 ;$ GFI $=0.910$, CFI $=$ 0.973 and TLI $=0.964$; RMSEA $=0.051$. All CR is in a range from 0.793 to 0.940 , which indicates that all constructs have internal consistency. Results shown in AMOS Output for factor loading have standardized regression weights; the lowest factor loading obtained is 0.697. All Average Variance Extracted (AVE) exceed 0.5. According to Hair et al. (2010), the most rigorous approach to test discriminant validity is a comparison between AVE for each factor with the squared inter-construct correlations associated with that factor. Overall, there is evidence to conclude the measurement model is good fit to examine further theoretical tests. Table 1 shows scale items and loadings.

Table 1: Scale items and loadings

\begin{tabular}{|c|c|}
\hline Scale & Factor loading \\
\hline \multicolumn{2}{|l|}{ Empower (AVE= 0.733; CR= 0.842) } \\
\hline \multicolumn{2}{|l|}{ When I work at X, I think ... } \\
\hline $\begin{array}{l}\text {...I do not have to get management's approval before I handle customer } \\
\text { problems }\end{array}$ & 0.99 \\
\hline ...I am allowed to do almost anything to solve customer problems & 0.697 \\
\hline \multicolumn{2}{|l|}{ Training $(\mathrm{AVE}=0.808 ; \mathrm{CR}=0.926)$} \\
\hline Employees of this retailer receive training on how to serve the customer better & 0.773 \\
\hline Employees in this retailer receive training on dealing with customer problems & 0.978 \\
\hline $\begin{array}{l}\text { Employees in this retailer receive training on how to deal with complaining } \\
\text { customers }\end{array}$ & 0.932 \\
\hline \multicolumn{2}{|l|}{ Customer orientation of a firm (AVE=0.768; CR=0.903) } \\
\hline $\begin{array}{l}\text { Senior management of this retailer is committed to doing its best for the } \\
\text { customer }\end{array}$ & 0.864 \\
\hline Senior managements' action back up a verbal commitment to customer service & 0.941 \\
\hline $\begin{array}{l}\text { Senior managers in this retailer go out of their way to ensure that customers are } \\
\text { satisfied }\end{array}$ & 0.82 \\
\hline \multicolumn{2}{|l|}{ Perceived Customer Information Sharing (AVE=0.692; CR=0.871) } \\
\hline I think customers always clearly explained what they wanted me to do. & 0.814 \\
\hline $\begin{array}{l}\text { I think customers provided the necessary information so that I could perform } \\
\text { my duties }\end{array}$ & 0.816 \\
\hline I think customers answered all the employee's service- related questions. & 0.865 \\
\hline \multicolumn{2}{|l|}{ Perceived Customer Personal Interaction (AVE=0.838; $C R=0.940)$} \\
\hline I think customers were kind to me when they came to complain & 0.879 \\
\hline I think customers were polite to me when they came to complain & 0.956 \\
\hline I think customers were courteous to me when they came to complain & 0.91 \\
\hline
\end{tabular}


Table 1: Continued

\begin{tabular}{|c|c|}
\hline \multicolumn{2}{|l|}{ Service recovery performance $(\mathrm{AVE}=0.695 ; \mathrm{CR}=0.820)$} \\
\hline Considering all the things I do; I handle dissatisfied customers quite well. & 0.797 \\
\hline I don't mind dealing with complaining customers. & 0.869 \\
\hline \multicolumn{2}{|l|}{ Job Stress (AVE=0.657; CR=0.793) } \\
\hline I am usually under a lot of pressure when I am at work. & 0.835 \\
\hline When I'm at work I often feel tense or uptight. & 0.785 \\
\hline \multicolumn{2}{|l|}{ Intention to leave $(\mathrm{AVE}=0.829 ; \mathrm{CR}=0.906)$} \\
\hline I often think about leaving this retailer. & 0.983 \\
\hline I will probably be looking for another job soon & 0.832 \\
\hline
\end{tabular}

Source: authors' work

Overall, five of seven estimates are consistent with the hypothesizes, these results support the hypothesis model with the caveat that two paths are not supported with a 95\% confidence interval. The empirical results are summarised in Figure 2.

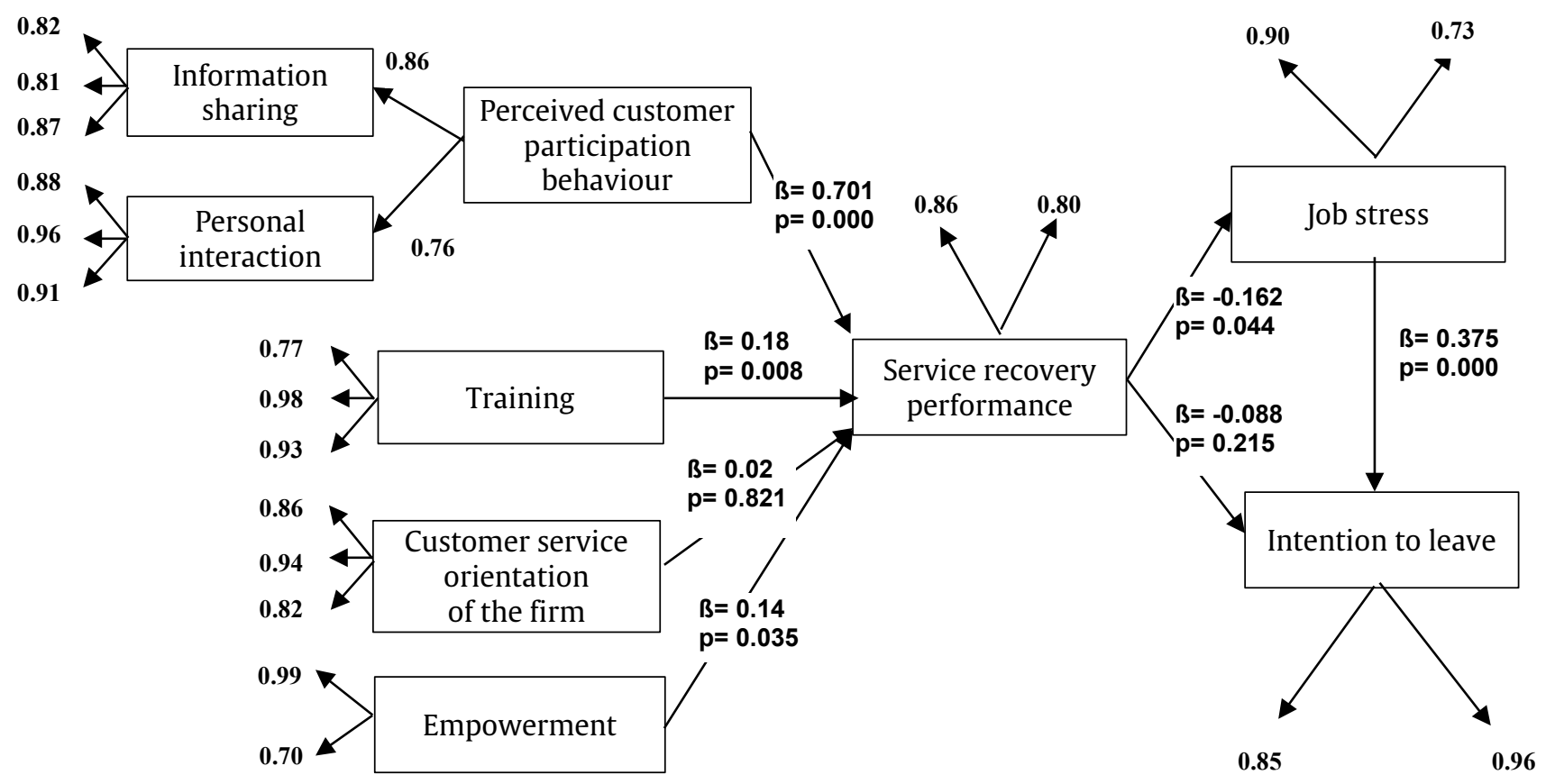

Figure 2: Structural equation model

Source: authors' work.

\section{DISCUSSION}

In general, this empirical study finds that the more frontline employees perceive customer participation in the recovery process, the more effectively they perform recovery, leading to lower job stress and an intention to leave. Perceived customer participation has the strongest impact on frontline employee service recovery performance (Beta $=0.701$, $\mathrm{p}$ - value= 0.000 ). When problems occur, it is necessary that customers share information about the current situation. Information is the first thing required by frontline employees to recover the issues, e.g.: when problems occur and the level of damage so 
that frontline employees can suggest a solution for the issues if possible or direct the issue to the right department which can then recover it. Moreover, customers are human beings, so it is understandable that they will be emotional when problems occur. Therefore, if customers are angry and out of control with their negative emotions, they may show inappropriate behaviours and share unclear information. Consequently, employees may not receive the proper and necessary information for the recovery process, and thus may not be able to perform their recovery efforts effectively.

Training and empowerment, in addition, have a positive impact on service recovery performance. Empowerment for frontline employees has a positive impact on service recovery performance, with $13.9 \%$ explaining the variance of service recovery performance. When a failure occurs, customers expect problems can be fixed immediately or at least have frontline employees suggest some possible solutions quickly. It thus appears as if frontline employees must be empowered to rectify service failures as they occur. Training for frontline employees has a positive impact on their service recovery performance, with $17.9 \%$ explained variance on service recovery performance. Training, then, is one of the major functions needed to provide the knowledge and skills for employees to recover from inevitable problems. Moreover, training helps employees to judge the current situation, e.g., whether problems came from employees' mistakes. Moreover, training over time is also necessary to let other employees learn from past mistakes. This result also indicates that the empowerment of and training for employees needs to be implemented simultaneously for more effective service recovery performance. This result is consistent with previous studies that show that training and empowerment engender employees' service recovery performance (e.g., Mihardjo et al, 2020; Masadeh, Al-Ababneh, and Al- Sabi, 2020).

The results of this study show that the service recovery performance of frontline employees has a negative impact on job stress with $16.2 \%$ explained variance. Because of the inconvenience from failures, customers tend to require having the problems fixed quickly, and sometimes they even expect higher quality as psychological compensation. From a company's view, the company will strive to fix its mistakes to win the customers back. Therefore, frontline employees are in the position to bear dual expectations from both sides. Consequently, the less effective service recovery frontline staff performs, the more stressful at work they feel. This hypothesis is supported in this study with pvalue $=0.000$ and Beta $=0.375$, showing that job stress has a strong impact on employees' intentions to leave. Recent results are also consistent about the relationship between service recovery performance and job stress (e.g., Zaman, Iftikhar, \& Rana, 2019).

Research results also show that the relationship between recovery and intention to leave among frontline employees is not supported in this study with a 95\% confidence interval. It can be said, however, that frontline employees may perceive their duty to fix customers' problems. Therefore, if frontline employees cannot perform recovery well, they do not think about leaving until the stress increases enough to threaten and affect their physical and mental health. This result is consistent with previous studies that show that employees who perform greater service recovery have less intention to leave (e.g., Boshoff and Allen, 2010; Wulansari et al, 2017).

Although the results do not support the relationship between customer service orientation and service recovery performance, it still is consistent with previous research (e.g., Boshoff và Allen, 2010). However, the positive relationship between customer service orientation and service recovery performance is consistent with the recommendation made by Rod and Ashill (2010). Therefore, the mixed results between those two constructs still require additional research.

\section{CONCLUSION}

With the aforementioned findings, this empirical research points out the important role of customer participation in frontline employee service recovery performance. In reference to the Service-Dominant Logic, this study is among a few studies to identify the role of customers in the delivery process. On the other hand, customers not only participate in the process and create value in use for themselves, but also are a 
contributor to creating value for both sides. This study confirms the significance of the interaction between customers and employees.

\section{Managerial Implications}

In general, the empirical results in the previous section emphasize the significance of customers. First, the research results show that perceived customer participation has the strongest impact on frontline employee service recovery performance. It can be said that retailers that would like to improve frontline employee service recovery performance can examine enhancing customer participation. It is necessary for employees to receive sufficient information from customers to perform their tasks. Therefore, retailers can design a more interactive recovery procedure to involve customers in this process. This not only helps employees understand customers' needs, but also helps confronts complaining customers. The result also indicates that training and empowerment have a positive impact on frontline employee service recovery performance. In addition, these results mean that the recovery process needs to be designed in a more interactive way, combined parallelly with training and empowerment. For more details about past issues, retailers can collect previous failure cases and the necessary information employees need from customers. Therefore, training and empowerment can provide sufficient knowledge and communication skills to respond quickly to customers. It is understandable that customers involved in the process and updated about the recovery status can gain a feeling of control over the recovery process and reduce their perceived risk and anxiety about the failure. Meanwhile, from the retailer's view, empowerment only works with the commitment of management. Therefore, managers should be trained and prepared to let their employees make mistakes and learn from there (Bell, 1992). Consequently, frontline employees can perform recovery more effectively and quickly.

More than that, when employees feel upset, worried, or frustrated at work, it may lead them to think about leaving. This research shows that job stress has a strong impact on employees' intention to leave, which is a significant implication because the retail industry is often faced with a high turnover rate (Coe, 1990). On the other hand, this suggests that retailers can decrease staff turnover by addressing factors that affect service recovery performance. Obviously, when employees are not able to recover from customers' problems effectively, they can increase their stress by listening to complaining customers, and because their salary is among the lowest-paid position in a retailer, it is easier for employees to think about leaving if the job creates too much stress. It is necessary, then, for retailers in Vietnam to inspire employees to view recovery as a chance to improve and create a friendly and supportive working environment to reduce perceived stress at work.

\section{Limitations and Further Research Directions}

This study archived research objectives to conduct and test a theoretical model about frontline employee service recovery performance in Vietnam, however there are a number of limitations which suggest areas for further research. This study solely focused on retailing in Ho Chi Minh City using convenience sampling. Therefore, it is unlikely to be representative of the population being studied. The latter research can expand the study to many more provinces in Vietnam. Moreover, this study would like to discover the role of the customer in service recovery performance, and many more factors from a company can affect employee service recovery performance that have not yet been examined. Further research can examine firm-related factors in the Vietnam context. Another limitation is that there are only 2 items that exist in the employee service recovery performance scale, which may not reflect the comprehensive meaning of this concept. Due to the small sample, this study could not examine further the moderating influence of demographic factors. Further work can also consider the applicability of this model across the different demographic groups.

\section{REFERENCES}

Andreassen, T. W., \& Lindestad, B. (1998). The effect of corporate image in the formation of customer loyalty. Journal of Service Research, 1(1), 82-92.

Ashill, N., Carruthers, J., \& Krisjanous, J. (2005). 
Antecedents and outcomes of service recovery performance in a public healthcare environment. Journal of Services Marketing, 19(5), 293-308.

Beehr, T. A., Walsh, J. T., \& Taber, T. D. (1976). Relationships of stress to individually and organizationally valued states: Higher order needs as a moderator. Journal of applied psychology, 61(1), 41.

Bell, C.R. (1992), "How to invent service", Journal of Services Marketing, Vol. 6 No. 1, pp. 37-9.

Bent, R., \& Freathy, P. (1997). Motivating the employee in the independent retail sector. Journal of Retailing and Consumer Services, 4(3), 201-208.

Boshoff, C., \& Allen, J. (2000). The influence of selected antecedents on frontline staff's perceptions of service recovery performance. International Journal of Service Industry Management, 11(1), 63-90.

Bowen D.E. and Lawler, E.E. (1992). “The empowerment of service workers: what, why, how and when", Sloan Management Review, Spring, pp. 31-9.

Brady, M. K., \& Cronin Jr, J. J. (2001). Customer orientation: Effects on customer service perceptions and outcome behaviors. Journal of service Research, 3(3), 241-251.

Cheung, F. Y. M., \& To, W. M. (2016). A customer-dominant logic on service recovery and customer satisfaction. Management Decision, 54(10), 2524-2543.

Coe, B. (1990). Executive turnover in the retailing sector in Gordon, Peter J. and Kellerman, J. Bert, Advances in Marketing. Southwest Marketing Association.

Cullen, F. T., Link, B. G., Wolfe, N. T., \& Frank, J. (1985). The social dimensions of correctional officer stress. Justice Quarterly, 2(4), 505-533

Dong, B., Evans, K. R., \& Zou, S. (2008). The effects of customer participation in cocreated service recovery. Journal of the academy of marketing science, 36(1), 123137.

Futrell, C. M., \& Parasuraman, A. (1984). The relationship of satisfaction and performance to salesforce turnover. Journal of Marketing, 48(4), 33-40.

Griffin, M. L., Hogan, N. L., Lambert, E. G., Tucker-Gail, K. A., \& Baker, D. N. (2010). Job involvement, job stress, job satisfaction, and organizational commitment and the burnout of correctional staff. Criminal Justice and behavior, 372), 239-255.

Gronroos, C. (1988). "Service quality: the six criteria of good perceived service quality", Review of Business, Vol. 9, Winter, pp. 10-3.

Guo, Y., Liu, Y., Oerlemans, A., Lao, S., Wu, S., \& Lew, M. S. (2016). Deep learning for visual understanding: A review. Neurocomputing, 187, 27-48.

Gwinner, K. P., Bitner, M. J., Brown, S. W., \& Kumar, A. (2005). Service customization through employee adaptiveness. Journal of Service Research, 8(2), 131-148.

Hair, J. F. (2010). Black, Wc, Babin, Bj, \& Anderson, Re (2010). Multivariate data analysis, 7.

Hayes, B.E. (1994). "How to measure empowerment", Quality Progress, February, pp. 41-6.

Hazée, S., Van Vaerenbergh, Y., \& Armirotto, V. (2017). Co-creating service recovery after service failure: The role of brand equity. Journal of Business Research, 74, 101-109.

Hennig-Thurau, T., Groth, M., Paul, M., \& Gremler, D. D. (2006). Are all smiles created equal? How emotional contagion and emotional labor affect service relationships. Journal of Marketing, 70(3), 58-73.

Krishna, A., Dangayach, G. S., \& Jain, R. (2011). Service recovery: Literature review and research issues. Journal of Service Science Research, 3(1), 71.

Masadeh, M., Al-Ababneh, M. M., \& Al-Sabi, S. M. A Comprehensive Research on Empowerment and Service Recovery Performance at Five-Star Hotels in Jordan.

Mihardjo, L. W., Jermsittiparsert, K., Ahmed, U., Chankoson, T., \& Hussain, H. I. (2020). Impact of key HR practices (human capital, training and rewards) on service recovery 
performance with mediating role of employee commitment of the Takaful industry of the Southeast Asian region. Education+ Training.

Parasuraman, A. (1987). “Customer-oriented corporate cultures are crucial to services marketing success", Journal of Services Marketing, Vol. 1 No. 1, pp. 39-46.

Paynevandy, S. G. (2016). The role of empowerment in Organization Development. Human Resource Management, 3(5), 9-16.

Pym A 2010. Exploring Translation Theories. London and New York: Routledge.

Rod, M., \& Ashill, N. J. (2010). Management commitment to service quality and service recovery performance. International Journal of Pharmaceutical and Healthcare Marketing.

Roggeveen, A. L., Tsiros, M., \& Grewal, D. (2012). Understanding the co-creation effect: when does collaborating with customers provide a lift to service recovery? Journal of the Academy of Marketing Science, 406), 771790.

Rust, R.T., Zahorik, A.J. and Keiningham, T.L. (1996). Service Marketing, Harper Collins, New York, NY

Schoefer, K., Wäppling, A., Heirati, N., \& Blut, M. (2019). The moderating effect of cultural value orientations on behavioral responses to dissatisfactory service experiences. Journal of Retailing and Consumer Services, 48, 247-256.

Thibaut, J. W., \& Walker, L. (1975). Procedural justice: A psychological perspective.

Vargo, S. L., \& Lusch, R. F. (2004). The four service marketing myths: remnants of a goods-based, manufacturing model. Journal of service research, 6(4), 324-335.

Wen, B., and C. G. Chi. (2013). "Examine the Cognitive and Affective Antecedents to Service Recovery Satisfaction: A Field Study of Delayed Airline Passengers." International Journal of Contemporary Hospitality Management 25 (3): 306-27.

Wulansari, Y. A., Koesmono, T., \& Junaedi, M. (2017). Pengaruh Keadilan Prosedural dan Stres Kerja terhadap Turnover Intention dengan Komitmen Organisasional sebagai Variabel Mediasi pada PT . PJB Services. Jurnal Ilmiah Mahasiswa Manajemen (JUMMA) Universitas Katolik Widya MandalaSurabaya, 6(2), 112-124.

Xie, C., Bagozzi, R. P., \& Troye, S. V. (2008). Trying to presume toward a theory of consumers as co-creators of value. Journal of the Academy of marketing Science, 36(1), 109-122.

Xu, X., Liu, W., \& Gursoy, D. (2019). The impacts of service failure and recovery efforts on airline customers' emotions and satisfaction. Journal of Travel Research, 58(6), 1034-1051.

Yi, Y., \& Gong, T. (2013). Customer value cocreation behavior: Scale development and validation. Journal of Business research, 66(9), 1279-1284.

Zaman, K., Rana, M. S., \& Iftikhar, U. (2019). A Multilevel Analysis of Job Demands and Intention to Resign Through Perceived Service Recovery Performance. Business \& Economic Review, 11(2), 67-82.

Zeithaml, V. A., Bitner, M. J., \& Dremler, D. (1996). Services Marketing, international edition. New York, NY and London: McGraw Hill.

\section{CORRESPONDING AUTHOR}

Tran Van Hung, email: hungtranvan7979@gmail.com 